\title{
The variation and propagation characteristics of meteorological, hydrological and agricultural droughts in mainland China
}

\author{
Huichao Zhao ${ }^{1}$, Ning $\mathrm{Yao}^{2}, \mathrm{Yi} \mathrm{Li}^{1}$, Asim Biswas ${ }^{3}$, and Hao Feng ${ }^{4}$ \\ ${ }^{1}$ Northwest A\&F University \\ ${ }^{2}$ Northwest Agriculture and Forestry University \\ ${ }^{3}$ University of Guelph \\ ${ }^{4}$ Institute of Soil and Water Conservation Chinese Academy of Sciences and Ministry of \\ Water Resources
}

April 28, 2020

\begin{abstract}
Drought, a natural hazard, greatly damages environment, agriculture, hydrology and thus, economy and our society at large. The national-scale variation and propagation characteristics of different types of droughts are critical for developing strategies and policies, while information is limited in China. This research investigated the evolution and propagation characteristics of three types of droughts using standardized indices; Standardized Precipitation Index (SPI), Standardized Soil Moisture Index (SSI) and Standardized Runoff Index (SRI) representing meteorological, agricultural and hydrological droughts based on precipitation (PPT), soil water storage (SWS) and baseflow-groundwater runoff (BGR), respectively at multi-timescales in different subregions of mainland China over 1948-2010. The most appropriate probability density distributions of PPT, SWS and BGR were selected for the calculation of drought indices and wavelet analysis was used to reveal their periodical characteristics. Modified Mann-Kendall trend test was used to compare the trend among drought indices. Pearson correlation coefficients were calculated to identify the lags of SPI with SSI and SRI. In general, SPI showed an agreement with the historical severe or extreme drought events at different sub-regions. The main periods of SSI were closer to SPI than SRI, indicating stronger connections of agricultural drought with meteorological drought. A weaker connection between meteorological and agricultural/hydrological droughts at shorter timescales was observed in northwestern arid and semi-arid regions. The propagation from meteorological to agricultural or hydrological droughts were well denoted by the lagged time (months) from SPI to SSI or SRI at a timescale ranged from 0 (mostly located in south China) to 5 months (mostly located in northeastern China) for certain timescale. The study provides crucial information and guidance to the policy makers in developing drought management strategies at regional to national scale and their critical time of action.
\end{abstract}

\section{Hosted file}

Manuscript.docx available at https : //authorea.com/users/313588/articles/444080-the-variationand-propagation-characteristics-of-meteorological-hydrological-and-agricultural-droughtsin-mainland-china

\section{Hosted file}

Tables. docx available at https : //authorea. com/users/313588/articles/444080-the-variation-andpropagation-characteristics-of-meteorological-hydrological-and-agricultural-droughts-in-mainlandchina

\section{Hosted file}


Figures.doc available at https://authorea.com/users/313588/articles/444080-the-variation-andpropagation-characteristics-of-meteorological-hydrological-and-agricultural-droughts-in-mainlandchina 